\title{
Pengembangan Alat Peraga dan Lembar Kerja Percobaan Penentuan Koefisien Restitusi untuk Meningkatkan Kemampuan Siswa Bereksperimen
}

\author{
Duden Saepuzaman ${ }^{1, a)}$, Yustiandi ${ }^{2, b)}$ \\ ${ }^{1}$ Fakultas Pendidikan Matematika dan Ilmu Pengetahuan Alam, Universitas Pendidikan Indonesia, \\ Jl. Dr.Setiabudhi 229, Dr.Setiabudhi 229, Bandung 40154 \\ ${ }^{2}$ SMAN Cahaya Madani Banten Boarding School \\ Jl. Raya Labuan Pandeglang km.3 Kuranten, Pandeglang 42210
}

Email: a)dsaepuzaman@upi.edu, b)yustiandi@yahoo.com

\begin{abstract}
This research is motivated because it found students' difficulties when experimenting to determine the magnitude of restitution coefficient. First, the determination of the initial height, the height of the second reflection and so on is not appropriate because it must observe something in a very short time. Second, the initial high determination is too high. Third, the object is oversize. Allegedly, existing worksheets do not facilitate students to experiment properly. This study aims to improve the experimental worksheet and redesign the experimental tool, so students will more easily understand how to experiment properly. This research is a classroom action research. Students' experimental abilities were obtained by comparing the answers of student worksheets before reconstruction and student answers after reconstruction. The results show that reconstructed worksheets can improve students' ability to experiment.
\end{abstract}

Keywords: Redesigning the appartures, Worksheets, Restitution Coefficients, Experimenting Skills.

\begin{abstract}
Abstrak
Penelitian ini dilatarbelakangi karena ditemukan kesulitan siswa ketika melakukan percobaan untuk menentukan nilai koefisien restitusi. Pertama, penentuan tinggi awal, tinggi pantulan ke dua dan seterusnya tidak tepat karena harus mengamati sesuatu dalam waktu yang sangat singkat. Kedua, Penentuan tinggi awal yang terlalu tinggi. Ketiga, ukuran benda yang terlalu besar. Diduga kuat, lembar kerja yang ada kurang memfasilitasi siswa untuk melakukan percobaan dengan benar. Penelitian ini bertujuan untuk memperbaiki lembar kerja percobaan dan mendesain ulang alat percobaan, sehingga siswa akan lebih mudah memahami cara melakukan percobaan dengan benar. Penelitian ini merupakan penelitian tindakan kelas. Kemampuan siswa bereksperimen diperoleh dengan cara membandingkan jawaban lembar kerja siswa sebelum direkonstruksi dan jawaban siswa setelah direkonstruksi. Hasil penelitian menunjukkan bahwa lembar kerja yang telah direkonstruksi dapat meningkatkan kemampuan siswa dalam bereksperimen.
\end{abstract}

Kata-kata Kunci: Pengembangan Alat Peraga dan Lembar Kerja Percobaan, Koefisien Restitusi, kemampuan bereksperimen. 


\section{PENDAHULUAN}

Metode eksperimen adalah suatu cara penyajian materi pelajaran yang mengondisikan siswa secara aktif mengalami dan membuktikan sendiri tentang apa yang sedang dipelajarinya. Melalui metode ini, siswa secara total dilibatkan dalam melakukan sendiri, mengikuti suatu proses, mengamati suatu objek, menganalisis, membuktikan dan menarik kesimpulan sendiri tentang suatu objek, keadaan atau proses (Zacharia 2007). Metode eksperimen adalah bagian yang tak terpisahkan dari Fisika. Oleh karena itu, kedudukan eksperimen dalam Fisika sangat penting. Dalam pelajaran fisika, eksperimen dapat melatih siswa dalam cara berfikir dan cara bekerja (Saepuzaman 2011).

Metode eksperimen siswa dilatih untuk menggunakan metode ilmiah dan sikap ilmiah secara benar dan sesungguhnya. Siswa dilatih untuk membaca data secara objektif menurut apa adanya, mengambil kesimpulan hanya berdasarkan fakta-fakta yang cukup mendukung, menyadari keterbatasan IPA, keterbatasan ketelitian suatu pengukuran, keterbatasan suatu hukum atau teori, memahami makna dari suatu teori dan sebaginya (Novili, dkk 2017). Hal-hal semacam ini sukar untuk dimengerti hanya dengan cara mendengarkan melalui ceramah.

Metode eksperimen memiliki beberapa kelebihan sebagai berikut. Pertama, metode ini dapat membuat siswa lebih percaya atas kebenaran atau kesimpulan berdasarkan percobaannya sendiri daripada hanya menerima dari guru atau dari buku saja.Kedua, dapat mengembangkan sikap untuk mengadakan studi eksplorasi tentang IPA dan teknologi. Ketiga, siswa terhindari dari verbalisme. Keempat, memperkaya pengalaman siswa akan hal-hal yang bersifat objektif dan realistik. Kelima, mengembangkan sikap berfikir ilmiah. Keenam, Hasil belajar akan terjadi dalam bentuk retensi (tahan lama diingat) dan terjadi proses internalisasi.

Dalam prakteknya, pelaksanaan eksperimen tidak semudah yang dibayangkan. Sebagai contoh dalam ketika melakukan percobaan untuk menentukan nilai koefisien restitusi. Kesulitan-kesulitan tersebut sebagai berikut. Pertama, penentuan tinggi awal, tinggi pantulan ke dua dan seterusnya tidak tepat karena harus mengamati sesuatu dalam waktu yang sangat singkat. Kedua, Penentuan tinggi awal yang terlalu tinggi. Ketiga, ukuran benda yang terlalu besar.

Keadaan ini mengindikasikan perlu adanya upaya rekonstruksi terhadap alat peraga dan lembar kerja sehingga dperoleh alat peraga dan lembar kerja yang standar sesuai dengan pendekatan ilmiah. Beberapa laporan penelitian sebelumnya menunjukkan bahwa rekonstruksi pembelajaran memegang peranan penting dalam proses pengembangan kurikulum pembelajaran fisika. Heuvelen (1991) berhasil mengintegrasikan beberapa strategi hasil penelitian kognitif dan pendidikan fisika ke dalam sebuah pembelajaran yang menekankan pada pemecahan masalah dan membangun konsep menggunakan multirepresentasi. Aiello-Nicosia dan Sperandeo-Mineo (2000) melakukan rekonstruksi terhadap konsten materi fisika yang diajarkan dan program pelatihan calon guru. Duit et al. (2012) memberikan sebuah kerangka kerja model rekonstruksi pendidikan yang menekankan bahwa salah satu dari tiga aspek yang penting dalam rekonstruksi adalah desain dan evaluasi lingkungan belajar. Karim et.al melakukan rekonstruksi pembelajaran pada materi momentum dan terbukti efektif dalam meningkatkan penguasaan konsep mahasiswa calon guru fisika (Saepuzaman \& Karim 2016). Saepuzaman, dkk merekostruksi Rencana Pelaksanaan Pembelajaran (RPP) dan lembar kerja Eksperimen dalam pembelajaran dan berhasil meningkatkan penguasaan konsep serta literasi saintifik siswa SMA (Saepuzaman \& Karim 2016, Juliani 2015, Karim, dkk 2017). Penelitian ini difokuskan pada desain ulang alat peraga dan lembar kerja untuk penentuan koefisien restitusi antar dua benda yang bertumbukan. Dasar pijakan yang utamanya adalah temuan kesulitan mahasiswa pada percobaan ini.

\section{METODE PENELITIAN}

Penelitian pengembangan ini diawali dengan tahapan deskriptif analitik untuk menganalisis permasalahan dan penyebab yang ditemukan sebagai bahan pertimbangan untuk mendesain ulang Alat Peraga dan Lembar Kerja Percobaan penentuan koefisien restitusi. Subjek penelitian sebanyak 42 siswa di salah satu SMA di Serang, Banten. Sebanyak 21 siswa menggunakan set alat dan lembar kerja dan alat yang belum didesain ulang sedangkan 21 siswa menggunakan set alat dan lembar kerja dan alat yang belum didesain ulang. Untuk mengetahui keefektifan dari desain ulang pembelajaran 
dalam peningkatan keterampilan eksperimen siswa ditentukan dengan cara membandingkan dan menganalisis jawaban lembar kerja siswa sebelum direkonstruksi dan jawaban siswa setelah direkonstruksi.

\section{HASIL DAN PEMBAHASAN}

\section{Desain Ulang Alat dan Lembar Kerja}

Beberapa permasalahan atau kesulitan siswa yang mucul dalam percobaan penentuan koefisien restitusi disajikan dalam TABEL 1.

TABEL 1. Permasalahan, analisis penyebab dan alternatif perbaikan percobaan penentuan koefisien resktitusi

\begin{tabular}{lll}
\hline Permasalahan & Analisis penyebab & Alternatif Perbaikan \\
\hline Percobaan & Ha ini dikarenakan penentuan tinggi & Upaya yang bisa dilakukan adalah \\
dilaksanakan & awal, tinggi pantulan ke dua dan & merekam track gerakan melalui video \\
sebanyak 5 & seterusnya tidak tepat karena harus & atau media lainnya. Hal ini dilakukan \\
kali, dan & mengamati sesuatu dalam waktu yang & selain untuk mengurangi kesalahan \\
menghasilkan & sangat singkat. & dalam pengukuran tinggi dan gerakan \\
nilai yang jauh & Penentuan tinggi awal yang terlalu & benda apakah benar-benar lurus atau \\
berbeda (tidak & tinggi. Hal ini dapat menyebabkan & tidak. \\
konstan/ & semakin besarnya faktor hambatan & Penentuan tinggi awal jangan terlalu \\
mendekati & udara, sehingga menyebabkan gerakan & tinggi. Hal ini untuk meminimalisir \\
konstan). & benda tidak lagi lurus dan & faktor hambatan udara. \\
& percepatannya tidak sepenuhnya & Ukuran benda yang digunakan usahakan \\
& konstan. Padahal formula akhir & kecil untuk menguarangi efek hambatan \\
& penentuan nilai koefisien restitusi & udara yang dialami benda selama \\
& diperoleh dengan mengasumsikan benda & pergerakannya. \\
& bergerak lurus dan dengan percepatan & \\
& konstan . & \\
& Ukuran benda yang terlalu besar. & \\
& Ukuran benda yang luas permukaannya & \\
& besar dapat memperbesar hambatan & \\
& udara. Seperti yang diketahui, besarnya & \\
& hambatan udara sebanding dengan besar & \\
& permukaan yang kontak (seperti & \\
& parasut). Selain itu juga ini sejalan & \\
dengan penggunaan formula akhir & \\
& koefisien restitusi bahwa benda yang & \\
ditinjau dipandang partikel, yang & \\
& ukurannya diabaikan sehingga efek yang & \\
& muncul hanya translasi saja. &
\end{tabular}

Sebagai contoh proses pengambilan data yang dilakukan salah satu kelompok disajikan dalam GAMBAR 1. 

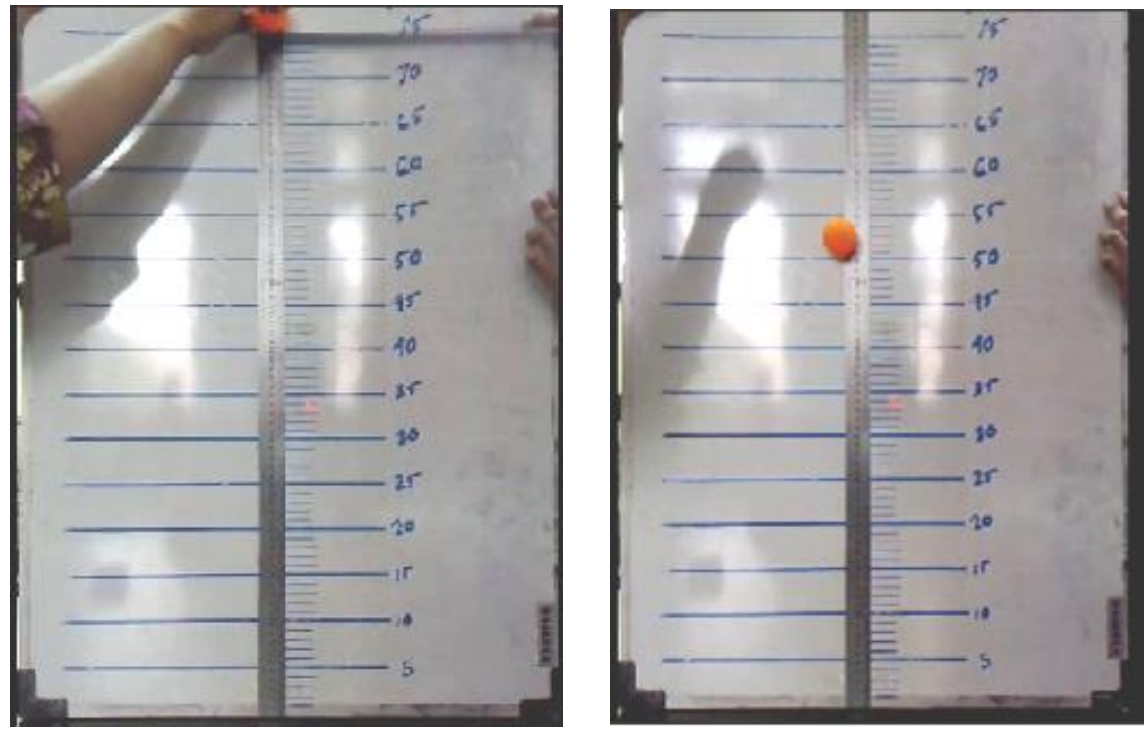

GAMBAR 1. Proses pengukuran ketinggian awal dan pantulan melalui video.

Dengan menggunakan video ini ternyata nilai koefisien yang diperoleh dengan menggunakan pengukuran berulang hasilnya tidak berbeda jauh (reliable) sehingga nilai simpangan bakunya juga kecil. Nilai yang diperoleh juga bisa dikatakan valid. Hal ini menunjukkan desain alat dan pengambilan data percobaan bisa dikatakan cukup efektif.

\section{Peningkatan Kemampuan Berkesperimen}

Kemampuan eksperimen yang dilatihkan pada mahasisiwa tingkat pemula dikelompokkan menjadi tiga bagian, kemampuan merencanakan, kemampuan bereksperimen/merancang dan mengambil data serta kemampuan hasil eksperimen (Brotosiswoyo 2000).

Kemampuan dalam menyiapkan kegiatan eksperimen meliputi; menggambarkan fenomena sains, menggambarkan karakteristik scientific theory, menggunakan hubungan matematik untuk meramalkan gambaran hasil observasi dan eksperimen, merumuskan hasil melalui estimasi, aproksimasi dan order of magnitude, mencari informasi yang dibutuhkan untuk mendapatkan hubungan antar variabel dan menambahkan informasi untuk menetapkan hubungan sebab akibat, mengidentifikasi variabel-variabel terkait, membuat prediksi berdasarkan asumsi yang diperoleh dari hasil hipotesis dan situasi eksperimen yang dibayangkan, dan mendesain eksperimen (menentukan prosedur dan langkah pengolahan data). Kemampuan dalam melaksanakan kegiatan eksperimen meliputi; merancang/mengeset alat eksperimen, memahami spesifikasi alat ukur yang diperlukan, mengetahui kondisi pengukuran, membaca satuan, menuliskan data eksperimen, melaporkan data hasil eksperimen, bekerja sama. Sedangkan untuk kemampuan dalam melaporkan hasil kegiatan eksperimen meliputi; melakukan pengolahan data dan melaporkan hasil, menginterpretasikan dan mengobservasi data untuk menunjukkan adanya hubungan antar variabel dan kecenderungan data, menjelaskan pemahaman dasar tentang kesalahan eksperimen dan menganalisis kesalahan eksperimen tersebut, mengorganisasi dan mengkomunikasikan hasil dari observasi dan eksperimen, baik secara kualitatif maupun kuantitatif, terampil menggunakan bahasa lisan maupun tulisan dan menyimpulkan hasil eksperimen. Secara umum, berdasarkan data yang terkumpul diperoleh hasil seperti yang disajikan dalam TABEL 2.

TABEL 2. Persentase kemampuan bereksperimen

\begin{tabular}{lll}
\hline \multirow{3}{*}{ Kemampuan Bereksperimen } & Kelompok & \\
\cline { 2 - 3 } & $\begin{array}{l}\text { Sebelum desain } \\
\text { ulang }(\%)\end{array}$ & $\begin{array}{l}\text { Setelah desain ulang } \\
(\%)\end{array}$ \\
\hline Menyiapkan & 28,9 & 43,2 \\
Melaksanakan & 39,5 & 39,7 \\
Melaporkan & 37,5 & 65,7 \\
\hline
\end{tabular}


Data pada TABEL 1 menunjukkan secara umum pencapaian kemampuan bereksperimen siswa yang telah menggunakan alat dan lembar kerja setelah desain ulang lebih besar dibanding sebelum desain ulang. Peningkatan terbesar terjadi pada aspek melaporkan hasil eksperimen. Analisis lebih lanjut ditemukan bahwa siswa lebih dapat melaporkan dan menganalisis data karena mereka dapat memperoleh data yang akurat.

\section{KESIMPULAN}

Mendesain ulang alat peraga telah dilakukan sebagai upaya perbaikan pembelajaran. Hasil impelementasi menunjukkan bahwa desain ulang yang dilakukan menghasilkan peningkatan kemampuan eksperimen yang lebih tinggi dibandingkan sebelum desain ulang. Hasil ini dapat dijadikan salah satu alternatif untuk diteraokan dalam pembelajaran momentum dan impuls, khusunya untuk materi penentuan koefisien restitusi pada kasus tumbukan lenting sebagian.

\section{REFERENSI}

Aiello-Nicosia, M. L., and R. M. Sperandeo-Mineo. "Educational reconstruction of physics content to be taught and of pre-service teacher training: a case study." International Journal of Science Education 22.10 (2000): 1085-1097.

Brotosiswoyo, Suprapto B, 2000. Hakekat Pembelajaran MIPA (Fisika) di Perguruan Tinggi, Proyek Pengembangan Universitas Terbuka Direktorat Jendral Pendidikan Tinggi Jakarta, Depdiknas.

Juliani, R. 2015. Rekonstruksi Rancangan Rencana Pelaksanaan Pembelajaran (RPP) Melalui Analisis Kesulitan Literasi Sains Peserta Didik Sekolah Menengah Pertama Pada Topik Listrik Dinamis (Doctoral dissertation, Universitas Pendidikan Indonesia).

Karim, S., Prima, E. C., Utari, S., Saepuzaman, D., \& Nugaha, M. G. 2017, February. Recostructing the Physics Teaching Didactic based on Marzano's Learning Dimension on Training the Scientific Literacies. In Journal of Physics: Conference Series (Vol. 812, No. 1, p. 012102). IOP Publishing.

Karim, S., Saepuzaman, D., \& Sriyansyah, S. P. 2016, August. The Learning Reconstruction of Particle System and Linear Momentum Conservation in Introductory Physics Course. In Journal of Physics: Conference Series (Vol. 739, No. 1, p. 012111). IOP Publishing.

Novili, W. I., Utari, S., Saepuzaman, D., \& Karim, S. 2017. Penerapan Scientific Approach dalam Upaya Melatihkan Literasi Saintifik dalam Domain Kompetensi dan Domain Pengetahuan Siswa SMP pada Topik Kalor. Jurnal Penelitian Pembelajaran Fisika, 8(1).

R. Duit et al., "Science Education Research and Practice in Europe: Retrospective and Prospective", in Doris Jorde and Justin Dillon (Eds.),Sense Publishers, 2012, pp. 13-37.

Saepuzaman, D. 2011. Penerapan Model Pembelajaran Inkuiri Dengan Kombinasi Eksperimen Nyata Virtual Pada Materi Rangkaian Listrik Arus Searah Untuk Meningkatkan Penguasaan Konsep dan Keterampilan Proses Sains Siswa SMA (Doctoral dissertation, Tesis Tidak diterbitkan. Bandung: Sekolah Pascasarjana Universitas Pendidikan Indonesia)

Saepuzaman, D., \& Karim, S. 2016. Desain Pembelajaran Student's Conceptual Construction Guider Berdasarkan Kesulitan Mahasiswa Calon Guru Fisika pada Konsep Gerak Parabola. Jurnal Penelitian \& Pengembangan Pendidikan Fisika, 2(2), 79-86.

Van Heuvelen, Alan. "Overview, case study physics." American Journal of Physics 59.10 (1991): 898-907.

Zacharia, Z .2007. Comparing and Combining Real and Virtual Experimentation: An Effort to Enhance Students' Conceptual Understanding of Electric Circiuits. Journal of Computer Assistes Learning. 23(2): 120-132. 
